\title{
Peningkatan prestasi belajar melalui strategi project-based learning mata pelajaran sosiologi SMA
}

\section{Indri Rosiana Dewi}

SMA Muhammadiyah 2 Yogyakarta. Jalan Kapas No.7, Kota Yogyakarta, Daerah Istimewa Yogyakarta 55166, Indonesia indrirosianasosiologi47@gmail.com

* corresponding author

\section{ARTICLE INFO}

Keywords

Project-Based Learning

prestasi belajar

sosiologi

\begin{abstract}
Penelitian ini bertujuan untuk meningkatkan prestasi belajar peserta didik pada mata pelajaran sosiologi melalui penggunaan strategi pembelajaran Berbasis Proyek (Project-Based Learning) dan untuk mengetahui peningkatan prestasi belajar siswa setelah penerapan strategi pembelajaran PjBL pada kelas XI IIS-3 di SMA Muhammadiyah 2 Yogyakarta. PTK ini dilakukan dalam 2 siklus dengan 2 pertemuan di setiap siklusnya. Kegiatan yang dilakukuan disetiap siklus adalah perencanaan, pelaksanaan, observasi, dan refleksi. Dalam strategi PjBL proses yang dilakukan dalam pembelajaran adalah pemaparan topik, perumusan masalah dasar, perencanaan proyek, pelaksanaan proyek, publikasi hasil proyek, dan evaluasi. Hasil penelitian menunjukkan kemampuan siswa dalam membuat proyek mengalami peningkatan kualitas dari $78 \%$ ke $81 \%$ meningkat $89 \%$. Peningkatan proyek diimbangi dengan peningkatan prestasi belajar dari $51 \%$ siswa yang tuntas menjadi $67 \%$ dan meningkat menjadi $78 \%$ siswa yang mengalami peningkatan prestasi belajar. Pembelajaran Berbasis Proyek dapat membuktikan dapat meningkatkan prestasi belajar siswa, mendorong peserta didik untuk mengembangkan dan mempraktikkan keterampilan komunikasi, meningkatkan keterampilan peserta didik dalam mengelola sumber dan memberikan pengalaman kepada peserta didik pembelajaran praktik dalam mengorganisasi proyek, dapat menambah pengalaman belajar serta membuat suasana belajar menjadi menyenangkan, sehingga peserta didik maupun pendidik menikmati proses pembelajaran.
\end{abstract}

This is an open access article under the CC-BY-SA license.

\section{PENDAHULUAN}

Setiap mata pelajaran memiliki karakteristik dan struktur keilmuan yang dapat membedakannya dengan mata pelajaran lainnya. Seperti halnya mata pelajaran sosiologi yang menekankan pembelajarannya untuk mempelajari perilaku dan interaksi sosial dalam masyarakat serta meneliti kelompok yang dibangunnya.

Pembelajaran yang ideal ditandai dengan sifatnya yang menekankan pemberdayaan siswa secara aktif. Hakikat pembelajaran ideal adalah proses belajar mengajar yang mampu memberikan pemahaman yang baik, kecerdasan dan ketekunan serta dapat memberikan perubahan perikau yang dapat di aplikasikan dalam kehidupan mereka (Qonitah \& Satyabakti, 2014). Dalam pembelajaran sosiologi peserta didik diharapkan mampu memahami keberadaan masyarakat dan dapat berinteraksi 
secara langsung dalam masyarakat dengan menunjukkan sikap toleransi terhadap perbedaan-perbedaan yang ada di masyarakat. Indikator keberhasilan belajar siswa dalam pelajaran sosiologi adalah bagaimana pemahanan siswa dalam memahami berbagai gejala sosial dalam masyarakat dan masalah-masalah apa yang mungkin muncul dalam masyarakat dengan melihat prestasi belajar siswa dalam proses pembelajaran.

Kenyataan dalam pembelajaran sosiologi, berdasar hasil ulangan pertama yang dilaksanakan oleh guru di kelas XI semester satu tahun pelajaran sebelumnya, yaitu tahun pelajaran 2015-2016. Dari hasil gambaran empiris tersebut dihasilkan kesimpulan bahwa jumlah siswa yang memperoleh nilai di bawah 76, standar KKM (Kriteria Ketuntasan Minimal) lebih dari 50\%. Rendahnya hasil belajar disebabkan beberapa faktor antara lain motivasi belajar kurang antusias dan penguasaan konsep siswa masih rendah. Peserta didik banyak yang merasa kesulitan dalam memahami pelajaran sosiologi yang diberikan guru karena kekurang serius merekan dalam menerima pelajaran sosiologi, serta kemampuan untuk memahami materi-materi sosiologi yang dirasakan susah, sehingga menyebabkan penguasaan konsep siswa dalam mata pelajaran sosiologi rendah. Untuk itu perlu adanya upaya tentang bagaimana agar prestasi belajar siswa dapat meningkat terutama dalam mata pelajaran sosiologi.

Upaya yang akan dilakukan guru untuk meningkatkan rerata nilai ulangan harian terutama materi perbedaan dan kesetaraan pada kelas XI IIS-3 tahun ajar 2016/2017 adalah dengan menerapkan model pembelajaran yang dapat meningkatkan prestasi belajar melalui. strategi pembelajaran yang yang dgunakan yaitu strategi pembelajaran Berbasis Proyek (Project-Based Learning)

Menurut Sani (2014, p. 172) pembelajaran Berbasis Proyek (Project-Based Learning=PjBL) merupakan strategi belajar mengajar yang lelibatkab siswa untuk mengerjakan sebuah proyek yang bermanfaat utuk menyelesaikan permasalahan dalam masyarakat atau lingkungan. Permasalahan yang dikaji merupakan permasalahan yang kompleks dan membutuhkan penguasaan materi pelajaran dalam upaya penyelesaiannya. Pembelajaran ini memungkinkan siswa untuk mengembangkan kreativitasnya dalam merancang dan membuat proyek yang dapat dimanfaatkan untuk mengatasi permasalahan.

Pembelajaran Berbasis Proyek (Project-Based Learning) adalah metoda pembelajaran yang menggunakan proyek/kegiatan sebagai media yang menggunakan masalah sebagai langkah awal dalam mengumpulkan dan mengintegrasikan pengetahuan baru berdasarkan pengalamannya dalam beraktifitas secara nyata. Metode PjBL mencakup kegiatan menyelesaikan masalah (problem solving), pengambilan keputusan, ketrampilan melakukan investifasi, dan ketrampilan membuat karya (Sani, 2014). Peserta didik harus fokus pada penyelesaian masalah atau pertanyan yang memandu mereka untuk memahami konsep dan prinsip yang terkait dengan proyek.

Kemampuan inteletual siswa sangat menebtukan keberhasilan siswa dalam belajar. Untuk mengetahui berhasil tidaknya seseorang dalam belajar, maka perlu melakukan suatu evaluasi yang bertujuan untuk menegtahui prestasi yang diperoleh siswa selama proses pembelajaran langsung. Prestasi belajar menurut Winkel (1983) adalah suatu keberhasilan proses belajar atau kemampuan siswa dalam melakukan kegiatan belajarnya sesuai dengan bobot yang dicapainya. prestasi belajar merupakan tingkat kemanusiaan yang dimiliki siswa dalam menerima, menolak dan menilai informasi-informasi yang diperoleh dalam proses pembelajaran

Rumini (1993, p. 60) menyebutkan bahwa prestasi pelajar dipengaruhi oleh dua faktor, yaitu: (a) Faktor yang berasal dari individu yang sedang belajar, (b) Faktor ini berupa minat siswa dalam belajar, maupun kondisi siswa ketika belajar, (c) Faktot yang berasal dari luar diri individu, (d) Faktor dari luar (eksternal) dapat berasal dari cara guru mengajar maupun kondisi aatu suasana kelas saat pembelajaran.

Jenis penelitian ini adalah Penelitian Tindakan Kelas (PTK). Penelitian tindakan kelas adalah penelitian tindakan yang dilakukan oleh guru dengan tujuan memperbaiki mutu praktik pembelajaran di kelas (Daryato, 2011). Penelitian Tindakan Kelas ini dilaksanakan dalam dua siklus sampai tercapainya tujuan penelitian yaitu meningkatkan prestasi belajar siswa. Penelitian ini dilakukan di SMA Muhammadiyah 2 Yogyakarta Jl. Kapas no.7 Yogyakarta, Kelas X IIS Semester Ganjil tahun 
ajaran 2016-2017 dengan kompetensi dasar memahami penerapan prinsip-prinsip kesetaraan dalam menyikapi keberagaman untuk menciptakan kehidupan harmonis dalam masyarakat. Subyek penelitian ini adalah siswa kelas XI IIS-3 yang berjumlah 32 peserta didik, yang terdiri atas 17 putra dan 15 putri. Dari semua siswa tersebut mempunyai tingkat kemampuan belajar yang berbeda serta pencapaian hasil yang variatif.

Penelitian ini dilaksanakan dalam 2 siklus yang setiap siklus terdiri dari dua pertemuan. Setiap siklus penelitian terdiri dari perencanaan tindakan, pelaksanaan tindakan, observasi dan refleksi. Dalam perencanaan tindakan yang dilakukan peneliti adalah menyusun rencana pelaksanaan pembelajaran (RPP), membagi siswa menjadi 7 kelompok dengan model acak dimana setiapkelompok terdiri dari 4-5 orang siswa, membuat penugasan keterampilan dan pedoman penilaian sebagai sarana dalam pelaksanaan Project-Based Learning, menyusun instrumen penelitian yang terdiri dari lembar observasi kegiatan siswa dan lembar observasi kegiatan guru saat proses pembelajaran.

Pada tahap pelaksanaan tindakan, Guru memaparkan topik yang dikaji,tujuan belajar, motivasi dan kompetensi yang akan dicapai, setiap kelompok mengidentifikasi permasalahan atau pertanyaan yang terkait dengan topik, membuat perencanaan proyek dan menetukan jadwal pelaksanaan proyek terkait dengan penyelesaian permasalahan yang diidentifikasi, kelompok menbuat proyek atau karya dengan memahami konsep yang terkait materi pelajaran, guru menfasilitasi pameran atas pekerjaan yang dihasilkan dan dan melaksanakan evaluasi materi pelajaran yang digunakan. Pada tahap observasi dilaksanakan oleh kolaborator yang melakukan pengamatan terhadap jalannya pelaksanaan tindakan. Tahap refleksi dilakukan setelah selesai pelaksanaan tindakan dengan melihat apakah dengan tindakan yang dilakukan dapat meningkatkan prestasi belajar. Hasil refleksi digunakan sebagai pedoman peneliti untuk merencanakan siklus berikutnya.

\section{HASIL DAN PEMBAHASAN}

Berdasarkan kegiatan yang telah dilaksanakan pada setiap siklus, sebanyak dua siklus dalam penelitian tindakan kelas ini sebagai upaya meningkatkan pemahaman mengenai praktek sistem bahan bakar konvensional pada siswa smk kelas XII jurusan tenik kendaraan ringan dengan menggunakan model pembelajaran Kooperatife tipe Jigsaw tergambar pada laporan hasil pembahasan yang diuraikan sebagai berikut: pada proses penelitian siklus I dan siklus II, Kegiatan yang dilakukan sebagai berikut:

\section{Perencanaan}

Dalam perencanaan ini, peneliti menyusun beberapa rencana untuk melaksankan tindakan diantaranya adalah sebagai berikut: (a) Membuat Rencana Pelaksanaan Pembelajaran (RPP); (b) Menyusun lembar Observasi; (c) menyusun soal tes kemampuan awal yang diberikan sebelum siksus dan evaluasi yang di berikan setiap akhir siklus.

\section{Tindakan/pelaksanaan}

Dalam tahap perencanaan ini adalah melaksanakan yang telah direncanakan sebelumnya yaitu: (a) Sebelum pembelajaran dimulai guru menyampaikan materi sesuai dengan RPP yang telah di buat; (b) Guru melaksanakan langkah langkah dalam KBM yang telah ditentukan diantaranya guru menjelaskan kepada siswa sesuai dengan pokok bahasan, kemudian membentuk kelompok untuk melakukan pembelajaran Kooperatif tipe Jigsaw kepada siswa; (c) Peneliti dan Teman Sejawat melakukan observasi terhadap aktifitas siswa pada saat siswa melakukan pembelajaran; (d) Guru melakuakn evaluasi tertulis terhadap Siswa secara individu untuk mengukur keberhasilan siswa dalam menyelesaikan latihan soal.

\section{Observasi}

Pada tahapan ini ditunjukan pada keaktipan siswa pada saat proses belajar mengajar berlangsung dengan meningkatkan pemahaman siswa pada mata pelajaran praktik engine pada materi bahan konvensional dengan menggunakan model pembelajaran kooperatif tipe Jigsaw (a) Pengamatan secara sistematis terhadap aktifitas siswa dalam proses pembelajaran berlangsung dan pada saat siswa menyelesaikan latihan soal berjalan dengan baik; (b) Pengamatan terhadap penerapan pembel- 
ajaran model kooperatif tipe Jigsaw dengan meningkatkan pemahaman siswa pada mata pelajaran praktik engine pada materi bahan bakar konvensional.

\section{Refleksi}

Pada tahap terakhir dalam proses siklus terakhir yaitu refleksi, ini bertujuan untuk merefleksikan hasil dari kegiatan selama proses belajar mengajar dan penemuan penemuan yang tercatat, lihat Tabel 1, pada saat pengamatan, baik hambatan, masalah dan lain sebagainya.

Tabel 1. Perolehan Nilai Prasiklus

\begin{tabular}{|c|c|c|c|}
\hline Penilaian & Rata-rata & Tuntas & Belum tuntas \\
\hline $\begin{array}{l}7560656887657374756577666074818283748570686560 \\
686474747674 \\
\text { Keterangan } \\
\text { Tuntas Belum Tuntas Belum Tuntas Tuntas Belum Tuntas Belum } \\
\text { Tuntas Belum Tuntas } \\
\text { Tuntas Belum Tuntas } \\
\text { Tuntas Belum Tuntas } \\
\text { Belum Tuntas Belum }\end{array}$ & 72 & 9 & 20 \\
\hline
\end{tabular}

\section{Pelaksanaan Siklus I}

Perencanaan

Pada tingkatan siklus I dilaksanakan dalam dua kali pertemuan yaitu pada tanggal 5 dan 6 September 2016 kegiatan yang dilakuakan adalah sebagai berikut; (a) Menyusun lembar observasi, yang terdiri dari lembar observasi kegiatan belajar siswa, dapat dilihat pada lampiran; (b) Menyusun Rencana Pelaksanaan Pembelajaran (RPP) tentang materi yang akan diajarkan sesuai dengan kompetensi dasar pemahaman tentang bahan bakar konvensional dalam meningkatkan pemahaman bakar konvensional; (c) Menyusun soal tes evaluasi berupa tes tertulis, hasil tes tertulis ini di gunakan untuk mengetahui nilai rata rata hasil belajar siswa. Soal tes dapat di lihat dalam lampiran. Selama melakukan tindakan peneliti dibantu oleh teman sejawat dalam melaksanakan proses belajar mengajar, dengan mengunakan lembar observasi dalam melaksanakan proses pembelajaran yang sedang berlangsung. Berdasarkan lembar observasi dan catatan lapangan deskripsi pelaksanaan yang di tetapkan adalah sebagai berikut: (1) Siswa dikelompokan sebanyak 1 sampai dengan 6 orang sisiwa; (2) Tiap orang dalam team diberi bagian materi berbeda; (3) Tiap orang dalam team diberi bagian materi yang ditugaskan; (4) Anggota dari team yang berbeda yang telah mempelajari bagian sub bagian yang sama bertemu dalam kelompok baru (kelompok ahli) untuk mendiskusiksn sub bab mereka; (5) Setelah selesai diskusi sebagai tim ahli tiap anggota kembali kedalam kelompok asli dan bergantian mengajar teman satu tem mereka tentang sub bab yang mereka kusai dan tiap anggota lainnya mendengarkan dengan seksama; (6) Tiap tem ahli mempresentasikan hasil diskusi; (7) Guru memberi evaluasi.

\section{Penutup}

Sebelum pembelajaran dimulai guru menyampaikan materi yang akan disajikan agar siswa lebih siap menghadapi pelajaran baru.

\section{Pelaksanaan Tes}

Pada pertemuan ke 2 hari Selasa tanggal 13 September 2016 dilaksanakan putaran siklus 1, kemudian di akhir pembelajaran dilakuakn tes dalam upaya untuk mengetahui hasil belajar siswa dan mengetahui motivasi siswa dalam menguasai materi yang telah di ajarkan. Dalam pelaksanaan tes terlihat ada beberapa siswa yang masih bekerjasama dengan temannya, kemudian penelti menegurnya agar menyelesaikan tes secara individu atau tidak boleh bekerjasama dengan ketentuan sekolah bahwa dikatakan tuntas jika memperoleh nilai 75. Skor individu siklus I. Nilai prasiklus terdapat 20 siswa yang masih rendah nilainya sedangkan 9 siswa sudah mencapai target ketuntasan belajar. Pada evaluasi hasil belajar siklus I terdapat 13 siswa yang masih rendah nilainya dan 16 siswa sudah 
mencapai ketuntasan belajar, hal ini dapat di bandingkan antara prasiklus dan evaluasi siklus I mencapai hasil peningkatan belajar.

Nilai rata-rata dari 29 siswa adalah 74 berdasarkan hasil tes siklus I, siswa yang tuntas 16 orang dan yang belum tuntas 13 orang atau berada pada kategori tuntas $66,7 \%$ dan sisanya yaitu kategori belum tuntas 33,3\%, walaupun nilai rata rata tes dari prasiklus sampai siklus I mengalami peningkatan, tetapi masih banyak siswa yang belum mencapai nilai ketuntasan yaitu 44,83\% dan masih berada dalam kategori tuntas 55,17\% maka peneliti akan melakukan tindakan selanjutnya yaitu dengan melakukan siklus II pada siswa kelas XII Teknik Kendaraan Ringan 2.

\section{Pelaksanaan pada siklus II}

\section{Perencanaan}

Perencanaan yang dilakukan selama pembelajaran siklus I hampir sama dengan siklus II merupakan hasil akhir belajar siswa agar mendapatkan hasil yang maksimal dan akhir pembelajaran siklus II, adapun yang dilakukan persiapan antara lain sebagai berikut:

Pertama, Menyusun lembar observasi, yang terdiri dari lembar observasi kegiatan belajar siswa, dan observasi kegiatan guru dapat dilihat pada lampiran. Kedua, Menyusun Rencana Pelaksanaan Pembelajaran (RPP) tentang materi yang akan di ajarkan sesuai dengan kompetensi Dasar Praktik Bahan Bakar Konvensional dalam meningkatkan pemahaman siswa. Ketiga, Menyusun soal tes evaluasi berupa tes tertulis, hasil tes tertulis ini di gunakan untuk mengetahui nilai rata rata hasil belajar siswa. Soal tes siklus II dapat dilihat dalam lampiran.

Data dari hasil observasi dan wawancara pada siklus I

Kegiatan obsevasi dibantu oleh teman menggunakan lembar observasi.hal ini didukung oleh hasil wawancara dan cacatan lapangan diperoleh data sebagai berikut:

Pertama, Pada siklus I hanya ada 3 siswa yang berani bertanya, dan hanya 4 orang siswa yang berani menjawab secara perorangan selebihnya dijawab hanya secara klasikal saja. Kedua, Ketika melakukan kerja kelompok siswa terlihat ribut dan bingung, karena tidak mengerti tugas yang harus dikerjakan, dan kelompok tidak terorganisir dengan baik. Ketiga, Waktu dalam pembelajaran perlu diefektifkan lagi. Keempat, Ketika guru menyampaikan materi siswa kurang memerhatikan penjelasan guru. Kelima, Pelaksanaan tes belum berjalan dengan baik hal ini di tunjukan dengan masih banyak yang bekerjasama atau mencontek pada saat mengerjakan tes.

\section{Refleksi pada siklus I}

Refleksi dilakukan untuk mengevaluasi pembelajaran pada siklus 1, kegiatan ini difokuskan pada masalah yang muncul selama pelaksanaan tindakan pada siklus 1 masih banyak kekuranga antara lain: Pertama, Penginformasian tujuan pembelajaran yang kurang sehingga siswa tidak jelas arah dari pembelajaran yang sedang dilakukan. Kedua, Kurangnya pemahaman guru dalam mengimplementasikan pembelajaran dengan menggunakan model kooperatif Jigsaw. Ketiga, Siswa masih banyak yang tidak memperhatikan guru saat menjelaskan materi pembelajaran.

Dari kekurangan-kekurangan tersebut maka perlu dilakukan untuk tindakan berikutnya, yaitu: (1) Peneliti menginformasikan tujuan pembelajaran lebih jelas lagi; (2) Guru harus lebih baik lagi membimbing siswa dengan menggunakan model kooperatif tipe Jigsaw; (3) Menegaskan kepada siswa agar pada saat guru menjelaskan materi dengan baik.

\section{Pelaksanaan pada siklus II}

Perencanaan

Perencanaan yang dilakukan selama pembelajaran siklus I hampir sama dengan sikls II merupakan hasil akhir belajar siswa agar mendapatkan hasil yang maksimaldan akhir pembelajaran siklus II, adapun yang dilakukan persiapan antara lain sebagai berikut; (1) Menyusun lembar observasi , yang terdiri dari lembar observasi kegiatan belajar siswa, dan observasi kegiatan guru dapat dilihat pada lampiran; (2) Menyusun Rencana Pelaksanaan Pembelajaran (RPP) tentang materi yang akan diajarkan sesuai dengan kompetensi Dasar Praktik Bahan Bakar Konvensional dalam meningkatkan 
pemahaman siswa; (3) Menyusun soal tes evaluasi berupa tes tertulis, hasil tes tertulis ini di gunakan untuk mengetahui nilai rata rata hasil belajar siswa. Soal tes siklus II dapat dilihat dalam lampiran.

\section{Pelaksanaan Siklus II}

Pelaksanaan pada siklus II di laksanakan selama dua kali pertemuan, pertemuan pertama pada siklus II dilaksanakan pada Senin, 19 September 2016. Peneliti melakuakn tindakan dengan melakukan pembelajaran kepada siswa antara lain: (1) Siswa dikelompokan sebanyak 1 sampai dengan 6 orang sisiwa; (2) Tiap orang dalam team diberi bagian materi berbeda; (3)Tiap orang dalam team diberi bagian materi yang ditugaskan; (4) Anggota dari team yang berbeda yang telah mempelajari bagian subbagian yang sama bertemu dalam kelompok baru (kelompok ahli) untuk mendiskusiksn subbab mereka; (6) Setelah selesai diskusi sebagai tem ahli tiap anggota kembali ke dalam kelompok asli dan bergantian mengajar teman satu tem mereka tentang subbab yang mereka kuasai dan tiap anggota lainnya mendengarkan dengan seksama; (7) Tiap tim ahli mempresentasikan hasil diskusi; (8) Guru memberi evaluasi; (9) Penutup.

Pelaksanaan tes evaluasi siklus II dilkasanakan pada hari selasa 20 September 2016 dengan materi akhir sub pokok bahasan. Tes siklus II dilaksanakan dengan baik dan siswa kelihatan sangat serius dalam mengerjakan soal dan sudah tidak terlihat siswa yang mencontek, karena peneliti dan guru benar benar mengontrol siswa dengan teliti dan ini merupakan siklus terakhir karena peneliti hanya menggunakan II siklus, Skor Individu, Skor perolehan siswa peningkatan individu diperoleh dengan cara membandingkan skor tes putaran I dan rata-rata skor tes siklius II. Data perolehan skor tes siswa ada peningkatan pada siklus II dalam pembelajaran terakhir, karena disini peneliti hanya menggunakan II siklus pada mata pelajaran Engine.

Kegiatan observasi di lakukan oleh peneliti dengan menggunakan lembar observasi hal ini untuk mengetahui siswa dalam ranah afektif dan psikomotorik. Hasil observasi aktifitas siswa pada siklus II mencapai $80 \%$. Dan hasil observasi guru sebesar $84.7 \%$ ini dapat di lihat pada lampiran lembar observasi dan di dukung hasil wawancara serta catatan lapangan sehingga memperoleh data sebagai berikut, pada siklus II terlihat aktif dalam belajar dengan menggunakan model Kooperatif tipe Jig Sho. Siswa terlihat tidak kaku lagi dalam melakukan kerja kelompok serta telihat antusias dalam dalam menjawab setiap pertanyaan yang di berikan oleh temannya

\section{Refleksi pada siklus II}

(1) Siswa sudah berani mengajukan pertanyaan tentang materi pelajaran yang belum diketahui baik terhadap teman atau gurunya; (2) Siswa menjawab pertanyaan guru secara klasikal sudah berkurang, siswa sudah berani menjawab perorangan; (3) Ketika guru menjelaskan siswa memperhatikan dengan baik. Sehingga materi engine dapat dipahami oleh siswa; (4) Dalam penyampaian materi pada kelompoknya siswa sudah terorganisir, sehinnga siswa tidak melakukan kegiatan lain seperti bercanda, bermain, atau mengganggu temannya; (5) Guru sudah memahami langkah-langkah model pembelajaran Kooperatif Tipe Jigsaw, sehingga kegiatan siswa sudah terarah sesuai dengan tujuan perbaikan pembelajaran; (6) Waktu yang digunakan dalam pembelajaran sudah efektif sesuai dengan skenario pembelajaran; (7) Hasil belajar siswa dalam pembelajaran engine materi bahan bakar konvensional makin faham.

Nilai rata-rata tes mengalami peningkatan, hal ini disebabkan karena pemahaman dan pengetahuan yang semakin bertambah. Pada siklus II ini hasil belajar siswa materi engine siswa teknik kendaraan ringan, $75,86 \%$ telah mencapai nilai ketuntasan belajar, sedangkan yang belum mencapai nilai ketuntasan belajar hanya 7 orang yaitu $24,14 \%$. Berdasarkan hasil penelitian di atas, menunjukan bahwa hasil belajar pada pelajaran engine dengan menggunakan model Kooperatif Tipe Jigsaw mulai dari siklus I sampai dengan siklus II terlihat ada peningkatan dalam pemahaman siswa pada praktik bahan bakar konvensional. Pada setiap siklus peneliti sudah berusaha menggunakan lima komponen dalam pendekatan pembelajarn model Kooperatif Tipe Jigsaw, pembelajaran lebih difokuskan untuk meningkatkan pemahaman siswa dengan meningkatkan pemahaman, kreatif. Dengan menggunakan kooperatif Tipe Jigsaw, siswa dituntut lebih aktif dalam pembelajaran, dan memperhatikan apa yang guru jelaskan dan siswapun terlihat berinteraksi bersama guru maupun antar siswa. 
Siklus II merupakan pemantapan tindakan siklus I dalam penggunaan lembar aktifitas siswa proses pembelajaran untuk mempermudah siswa dalam memahami materi dengan menggunakan, kooperatif Tipe Jigsaw pada mata pelajaran engine. Berdasarkan hasil penelitian di atas, menunjukan bahwa hasil belajar pada pelajaran engine dengan menggunakan model Kooperatif Tipe Jigsaw mulai dari siklus I sampai dengan siklus II terlihat ada peningkatan dalam pemahaman siswa pada praktik bahan bakar konvensional. Gambaran hasil kemampuan siswa selama berlangsungnya pembelajaran dengan menggunakan model Kooperatif Tipe Jigsaw, dapat dilihat data tes pada Tabel 2 , tentang evaluasi siswa yang sudah dilakukan pada penelitian ini.

Tabel 2. Rata-rata Skor tes dari setiap tes

\begin{tabular}{cc}
\hline Hasil untuk Skor Tes & Rata-rata Skor tes \\
\hline Prasiklus & 71.86 \\
Siklus I & 73.62 \\
Siklus II & 75.04 \\
\hline
\end{tabular}

Jadi, dari Tabel 2 dapat disimpulkan bahwa ada peningkatan dari setiap siklusnya karena ketuntasan disekolah hanya 75 , maka target sudah tercapai dan pemahaman siswa pada mata pelajaran engine juga meningkat. Pada setiap siklus peneliti sudah berusaha menggunakan lima komponen dalam pendekatan pembelajarn model Kooperatif Tipe Jigsaw, pembelajaran lebih dipokuskan untuk meningkatkan pemahaman siswa dengan meningkatkan pemahaman, kreatif. Dengan menggunakan kooperatif Tipe Jigsaw, siswa dituntut lebih aktif dalam pembelajaran, dan memperhatikan apa yang guru jelaskan dan siswa pun terlihat berinteraksi bersama guru maupun antar siswa. Siklus II merupakan pemantapan tindakan siklus I dalam penggunaan lembar aktifitas siswa proses pembelajaran untuk mempermudah siswa dalam memahami materi dengan menggunakan, kooperatif Tipe Jigsaw pada mata pelajaran engine.

Selanjutnya dilakukan peneliti dalam dua siklus, pada siklus I terlihat bahwa persentase skor tes siswa mencapai $73,62 \%$. hal ini menunjukan bahwa siswa belum sepenuhnya mencapai ketuntasan belajar. Sedangkan pada siklus II telah mengalami penigkatan persentase tes siswa mencapai $75,04 \%$, hal ini menunjukan ada peningkatan persentase ketuntasan belajar siswa pada siklus II di sebabkan adanya peningkatan motivasi siswa dalam belajar. Peningkatan tersebut menandakan adanya peningkatan hasil belajar pada materi bahan bakar konvensional pelajaran engine. Walaupun pada dasarnya model Kooperatif Tipe Jigsaw bukan satu satunya metode yang bisa digunakan pada mata pelajaran engine, akan tetapi pada hal ini kenyataannya dapat membantu siswa dalam memahami mata pelajaran engine. Namun hal tersebut juga perlu didukung dengan adanya kemauan dari para siswa untuk mempelajari engine dengan lebih giat lagi agar motivasi siswa tentang materi yang dipelajari diharapkan dapat diaplikasikan dalam kehidupan sehari hari. Berdasarkan pemaparan diatas menunjukan bahwa melalui model pembelajaran kooperatif tipe Jigsaw pada mata pelajaran engine materi bahan bakar konvensional menjadi meningkat. Semua itu terlihat dari adanya ketuntasan belajar siswa dari siklus I sampai siklus II.

\section{Deskripsi hasil penelitian Siklus I}

Siklus I dilaksanakan dalam 2 pertemuan. Pertemuan pertama pada hari sabtu tanggal 1 Oktober dan pertemuan 2 pada hari selasa tanggal 4 Oktober 2016. Gambaran pelaksanaan Siklus I dapat diuraikan sebagai berikut:

\section{Tahap perencanaan}

Tahap perencanaan pada pertemuan 1 dan 2 yang dilakukan peneliti adalah menyusun rencana pelaksanaan pembelajaran (RPP) dengan sub materi stratifikasi sosial,membagi siswa menjadi 7 kelompok dengan model acak dimana setiap kelompok terdiri dari 4-5 orang siswa,membuat penugasan keterampilan dan pedoman penilaian sebagai sarana dalam pelaksanaan Project Based Learning, menyusun instrumen penelitian yang terdiri dari lembar observasi kegiatan siswa dan lembar observasi kegiatan guru saat proses pembelajaran tentang stratifikasi sosial, membuat daftar pertanyaan wawancara yang berkaitan dengan proses pembelajaran dan memaparkan topik yang akan dikaji. 
Tahap pelaksanaan Tindakan

Guru memaparkan topik dan tujuan pembelajaran serta kompetensi yang akan dicapai. Peserta didik mengidentifikasi permasalahan atau pertanyaan yang terkait dengan topik stratifikasi sosial, membuat kelompok belajar, perencanaan proyek dan menetukan jadwal pelaksanaan proyek yang terkait dengan penyelesaian permasalahan yang teridentifikasi. Kelompok menbuat proyek atau karya dengan memahami konsep yang terkait materi pelajaran. Guru memfasilitasi pameran atas pekerjaan yang dihasilkan dan dan melaksanakan evaluasi materi pelajaran yang digunakan.

\section{Tahap Observasi Tindakan}

Berdasarkan observasi pembelajaran yang dilakukan kolaborator, data hasil observasi pembelajaran pada siklus I pertemuan satu dan dua tersaji sebagai berikut: Kegiatan setiap pertemuan diawali dengan salam sebagai pembuka pelajaran. Guru memberikan apersespsi serta motivasi agar siswa mengingat kembali materi yang lalu tentang pengertian dan karakteristik stratifikasi sosal. Guru menyampaikan tujuan pembelajaran yaitu siswa dapat memahami penerapan prinsip- prinsip kesetaraan dalam menyikapi keberagaman dalam masyarakat dan siswa mampu merumuskan strategi dalam menciptakan kehidupan yang harmonis alam masyarakat.

Pada kegiatan inti guru menjelaskan konsep analisis fakta yang terdapat dalam masyakat tentang dampak yang ditimbulkan dai lapisan- lapisan sosial di masyarakat. Guru membentuk 7 kelompok kerja yang beranggotakan 4-5 siswa. Guru menjelaskan dampak stratifikasi di dalam masyakat dan siswa dalam kelompoknya memperhatikan. Dalam proses ini ada beberapa siswa yang tidak konsentrasi belajar. Sehingga pembelajaran sedikit riuh. Sering guru memberi arahan tegas yetntang siswa yang menggangu proses pembelajaran. Setelah penjelasan materi selesai, siswa diberikan kesempatan bertanya namun tidak ada siswa yang bertanya. Guru memberikan pertanyaan dasar yang memancing siswa membuat proyek. Setiap kelompok menyusun strategi tentang cara meminimalkan dampak negatif stratifikasi sosial. Proyek dibuat dengan progam komputer dengan menggunakan progam words maupun power point. Hal ini dilakukan karena hasil proyek akan di masukkan di web pembelajaran sosiologi sebagai sarana pameran kepada masyarakat.

Guru memdampingi dan memonitor dalam diskusi setiap kelompok. Setiap kelompok mengkonsultasikan jawaban kepada guru. Pada proses ini terlihat ada beberapa kelompok yang belum jelas tentang tugas yang harus dilaksanakan. Setelah proyek selesai para siswa mempresentasikan hasilnya didepan kelas. Dalam proses presentasi belum semua siswa memperhatikan. Hal ini terlihat dari hasil pengamatan diskusi dan presentasi. Pada proses terakhir PjBL diakhir dengan proses publikasi. Setiap kelompok yang sudah lolos dalam presentasi mengirimkan hasilnya ke email guru untuk di publikasikan di web pembelajaran sosiologi. Ini sebagai cara yang ditempuh untuk sarana pameran yang dilakukan secara online. Karena faktor kurang paham dan kurang kondusif siswa dalam pembelajaran. Hasil produk proyek yang dihasilkan kelompok masih rendah. Hanya sekitar 3 sampai 4 kelompok yang hasilnya memuaskan. Kemampuan memahami penerapan prinsip-prinsip kesetaraan dalam menyikapi keberagaman dalam masyarakat $67 \%$ dengan kategori cukup. Hal tersebut menunjukkan bahwa tingkat keberhasilan pembelajaran proyek pada siklus I belum maksimal karena belum mencapai ketuntasan belajar klasikal seperti yang telah ditetapkan, yaitu 75\% siswa. Di akhir kegiatan, guru membantu siswa melakukan refleksi dan menyimpulkan kegiatan yang telah dilakukan. Guru mengingatkan siswa untuk menyempurnakan proyek yang disusun sebagai persiapan materi pertemuan berikutnya. Guru mengakhiri pelajaran dengan salam penutup.

Tahap Refleksi

Kegiatan yang dilakukan pada tahap refleksi adalah mengkaji ulang hasil pelaksanaan pembelajaran pada pertemuan pertama dan kedua untuk menentukan langkah perbaikan pada pelaksanaan siklus II. Prestasi siswa dalam pembuatan proyek pada pertemuan pertama dan dua belum mencapai target. Karena ditemukan dari faktor guru dan siswa. Kurang jelasnya guru dalam memberikan pertanyaan dasar dan dari siswa adanya rasa bingung dengan model pembelajaran yang dilaksananakan. 


\section{Deskripsi Hasil Penelitian Siklus II}

Pelaksanaan siklus II juga terbagi dalam 2 pertemuan dengan proses pelaksanan yang hampir sama dengan siklus sebelumnya. Perbedaan yang terdapat pada siklus II adalah pemilihan materi yang berbeda. Berikut gambaran proses pelaksanaan pada siklus II:

Tahap Perencanaan

Kegiatan yang dilakukan pada tahap perencanaan ini adalah melaksanakan kegiatan sesuai dengan desain yang telah dibuat sebelumnya. Semua persiapan telah dilakukan setelah diskusi dengan kolaborator, baik dari rencana pelaksanaan pembelajaran maupun menyiapkan alat-alat yang akan digunakan. Tahapan perencanaan dibuat berdasarkan hasil evaluasi dan refleksi terhadap pelaksanaan siklus I.

\section{Pelaksanaan Tindakan dan Observasi}

Pelaksanaan tindakan siklus II pada pertemuan pertama dan kedua tidak jauh beda dengan siklus sebelumnya. Pelaksanakan siklus II pada hari hari Sabtu, 22 Oktober dan hari hari selasa tanggal 1 November 2016 Pada tahap ini Guru memaparkan topik dan tujuan pembelajaran, serta kompetensi yang akan dicapai. Peserta didik mengidentifikasi permasalahan atau pertanyaan yang terkait dengan topik deferensiasi sosial, setiap kelompok belajar yang beranggotakan empat atau lima peserta didik membuat perencanaan proyek dan menetukan jadwal pelaksanaan proyek terkait dengan penyelesaian permasalahan yang diidentifikasi, kelompok menbuat proyek atau karya dengan memahami konsep yang terkait materi pelajaran, guru menfasilitasi pameran atas pekerjaan yang dihasilkan dan dan melaksanakan evaluasi materi pelajaran yang digunakan.

\section{Observasi Tindakan}

Berikut hasil pengamatan observer terhadap aktivitas guru dan siswa dalam mengajar di siklus II pertemuan 1 dan 2 . Guru memulai pelajaran dengan salam pembuka serta memberikan apersepsi tentang pengertian dan dampak diferensiasi sosial yang telah dipelajari pada pertemuan sebelumnya. Guru memotivasi siswa agar siswa lebih semangat dalam pelaksanaan pembuatan proyek dengan memperhatikan tahap-tahap dalam pembelajaran PjBL. Pada siklus II siswa terlihat lebih siap dalam mempersiapkan alat yang dipergunakan untuk membuat proyek. Guru menyampaikan kembali tujuan pembelajaran yang akan dicapai di akhir pembelajaran. Setelah itu, siswa diminta duduk bersama kelompoknya masing-masing.

Pada kegiatan inti guru menerangkan kembali sedikit materi yang belum jelas bagi siswa pada siklus I. Siswa menyimak penjelasan guru dan mencatat kesalahan-kesalahan pada saat pelaksanaan pembuatan proyek. Guru memberikan pertanyaan kepada siswa untuk di bahas dalam kelompok tentang strategi yang harus dibuat umtuk menangani dampak negatif diferensiasi sosial bagi masyarakat. Siswa bersama guru mendesain perencanaan proyek dan menyusun jadwal pelaksanaan. Dalam kesepakatan 20 menit diskusi dan dilanjutkan dengan presentasi. Bersama kelompoknya siswa menyusun strategi penanganan dampak deferensiasi dalam powerpint. Tidak lupa guru membimbing siswa agar semua anggota kelompok terlibat aktif dalam kelompoknya. Waktu pengerjaan proyek telah selesai dan setiap kelompok menyiapkan presentasinya. Siswa mempresentasikan hasil proyeknya, kelompok lain siswa dari kelompok lain memberikan tanggapan terhadap kelompok yang maju. Setelah proses presentasi selesai, hasil proyek dikumpulkan ke guru untuk dimasukkan ke web pembelajaran sosiologi sebagai sarana publikasi. Dari 7 kelompok yang presentasi pada pertemuan 1 ada 4 yang presentasi dan pertemuan 2 ada 6 kelompok tampil kedepan untuk presentasi. Hal tersebut menunjukkan bahwa tingkat keberhasilan pembelajaran proyek pada siklus II meningkat. Berikut Tabel 3 peningkatan hasil proyek setiap siklus secara prosentase.

Peningkatan hasil proyek dibarengi dengan peningkatan prestasi belajar siswa. Berdasarkan pengambilan nilai pada siklus II, siswa yang telah mencapai ketuntasan belajar klasikal dari $67 \%$ pada pelaksanaan siklus I dan pada siklus II meningkat menjadi $78 \%$ siswa. Berikut perbandingan prestasi belajar $\mathrm{x}$ dari sebelum proses dan setelah proses pelaksanaan tindakan. 
Tabel 3. Perbandingan hasil proyek pada setiap siklus

\begin{tabular}{clcccc}
\hline \multirow{2}{*}{ No. } & \multirow{2}{*}{ Indikator } & \multicolumn{2}{c}{ Siklus I } & \multicolumn{2}{c}{ Siklus II } \\
\cline { 3 - 5 } & & Pertemuan 1 & Pertemuan 2 & Pertemuan 1 & Pertemuan 2 \\
\hline 1. & Perencanaan & $63 \%$ & $73 \%$ & $82 \%$ & $81 \%$ \\
2. & Proses pembuatan proyek & $81 \%$ & $70 \%$ & $77 \%$ & $89 \%$ \\
3. & Produk proyek & $78 \%$ & $81 \%$ & $81 \%$ & $89 \%$ \\
\hline
\end{tabular}

Tabel 4. Perbandingan prestasi belajar siswa

\begin{tabular}{cccc}
\hline & Sebelum tindakan & Tindakan siklus I & Tindakan sikus II \\
\hline Jumlah siswa & 32 & 32 & 32 \\
Jumlah siswa yang tuntas & 18 & 21 & 25 \\
Jumlah siswa yang belum tuntas & 17 & 11 & 7 \\
Rerata & 65 & 70 & 77 \\
Prosentase ketuntasan & $51 \%$ & $67 \%$ & $78 \%$ \\
\hline
\end{tabular}

Aktivitas guru membimbing siswa untuk aktif dalam kegiatan pembelajaran pada pertemuan $1 \mathrm{di}$ siklus I masih sangat kurang. Guru lebih banyak memberikan ceramah dan semua siswa belum bisa konsentrasi belajar sehingga belum semua siswa paham mengenai proyek yang harus diselesaikan. Siswa yang aktif dalam pembuatan proyek dalam kelompok hanya beberapa anggota dan anggota kelompok yang lain masih banyak yang sibuk dengan gadget nya dan saling bercanda. Pada pertemuan ke-2 pada siklus I, guru berusaha meningkatkan kegiatan mengajukan pertanyaan yang membuat siswa lebih tertarik terhadap kegiatan pembelajaran. Guru berusaha membimbing dan memotivasi siswa dengan memberikan arahan dalam pembuatan proyek di setiap tahapnya sehingga dicapai pembelajaran yang lebih baik.

Aktivitas siswa selama pembelejaran dari siklus I menunjukkan peningkatan yang cukup. Aktivitas siswa pada siklus I pertemuan 1 dalam kemampuan berpendapat dalam kelompok proyek masih dikategorikan rendah. Beberapa siswa masih belum paham apa yang harus dikerjakan dan membuat proyek. Tetapi pada pertemuan 2 aktivitas siswa sudah lebih baik karena pada siswa sudah mulai konsentrasi dalam pelaksanaan proyek di kelompok mereka masing-masing . Prestasi belajar yang dicapai siswa pada siklus I tergolong masih cukup rendah. Siswa belum dapat menjawab pertanyaan tertulis secara tepat. Hal itu terjadi karena kekurang seriusan siswa dalam belajar. Dari siswa yang berjumlah 32 orang, yang tuntas hanya 21 orang. Kalau di prosentasekan jumlah siswa yang tuntas baru $60 \%$. Nilai rerata pada siklus I adalah 70

\section{Deskripsi Siklus II}

Pada pembelajaran siklus II di pertemuan 1 guru berusaha meningkatkan keterlibatan siswa dalam pembelajaran dengan penekanan pada pembelajaran dengan strategi PjBL. Siswa tampak lebih antusias pada kegiatan pembelajaran. Begitu pula dengan pertemuan-pertemuan berikutnya, guru sudah dapat meningkatkan kualitas pembelejaran. Pada pembelajaran siklus II di pertemuan 2, guru hanya sedikit dalam memberi arahan kepada siswa. Siswa lebih kondusif dalam belajar walaupum masih ada 2 anak yang belum maksimal dalam konsentrasi belajarnya. Pertanyaan besar yang disampaikan guru kepada siswa dalam rangka pembuatan proyek langsung bisa dilaksanakan oleh setiap kelompok. Aktivitas guru dalam menjawab pertanyaan di setiap kelompok proyek pada siklus II di pertemuan 1 dan 2 dikatakan baik dan lebih meningkat yang berarti kegiatan tersebut relevan dengan materi tetapi belum dapat menarik perhatian siswa. Di pertemuan berikutnya guru berusaha menigkatkan kualitas kegiatan tersebut dan memberikan penguatan hingga siswa mampu melaksanakan perannya dalam pembuatan proyek di dalam kelompoknya. Prestasi belajar siswa pada siklus II cenderung meningkat. Hal itu dapat dilihat dari kenaikan jumlah prosentase nilai yang tuntas. Dari jumlah 35 siswa di klas XI IIS-3, yang mempunyai nilai tuntas ada 28 siswa dan bila diprosentase sekitar $78 \%$ dengan nilai rerata kelas 77

Secara keseluruhan aktivitas guru dan siswa selama pembelajaran siklus I sampai dengan siklus II di setiap pertemuan dapat digambarkan dalam Gambar 1 dan Gambar 2.: 
Siklus II

Aktivitas Guru

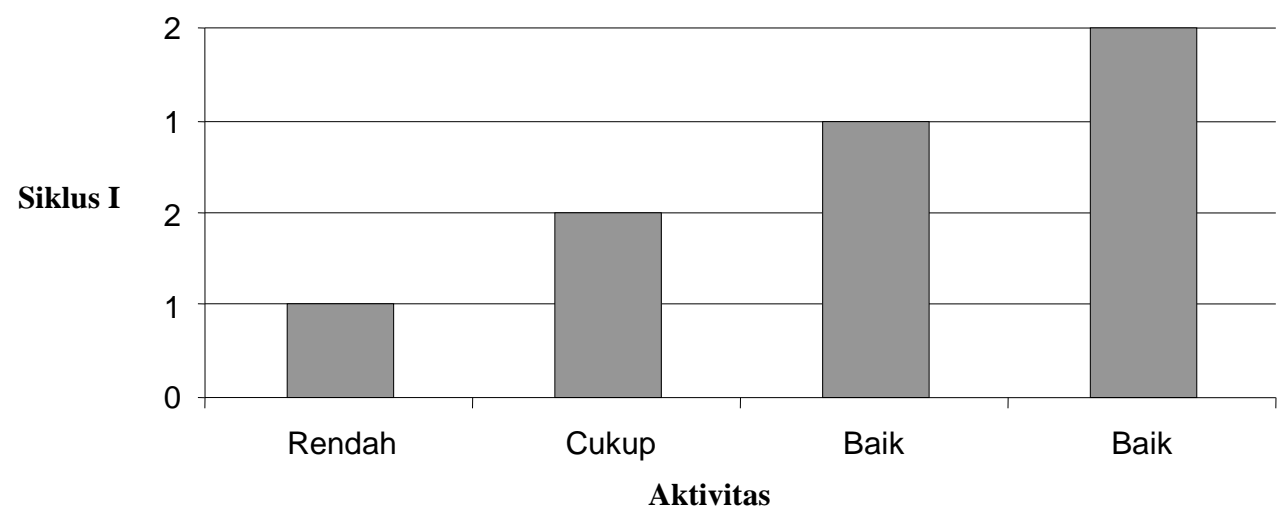

Gambar 1. Aktivitas guru dalam setiap pertemuan dalam siklus I dan II

Siklus II

Aktivitas Siswa dalam kerja kelompok

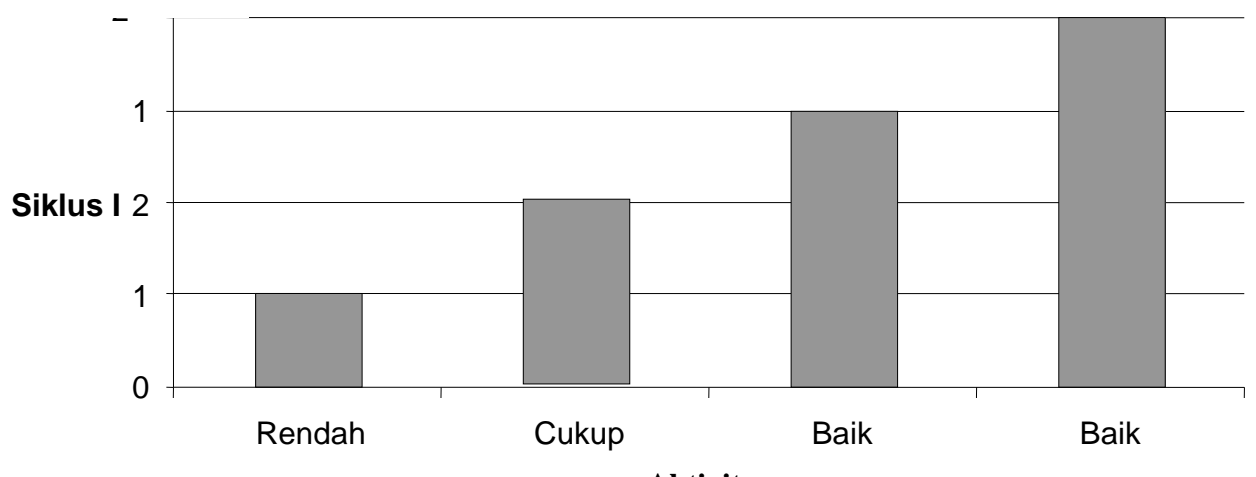

Gambar 2. Aktivitas siswa dalam kerja kelompok disetiap pertemuan di siklus I dan II

\section{Peningkatan prestasi belajar siswa setelah penerapan strategi PjBL}

Peningkatan prestasi belajar yang dihasilkan dari penerapan strategi PjBL dapat dilihat dari data perbandingan antara pretasi belajar siswa sebelum tindakan, setelah pelaksanaan tindakan siklus I dan setelah pelaksanaan tindakan di siklus II. Lebih jelasnya prestasi belajar dari kondisi awal sebelum tindakan, siklus I dan siklus II dapt dilihat dari Gambar 3. Gambar grafik menunjukkan bahwa prestasi siswa dari setiap siklusnya mengalami peningkatan. Hal itu dapat terjadi karena setiap siklusnya aktivitas guru semakin mengalami kemajuan sehingga materi yang disampaikan semakin dapat dipahami siswa. Kondisi siswa pun semakin kondusif walaupun ada 5 anak yang sering usil dalam roses pembelajaran Pembelajaran. pada kondisi awal prosentase siswa yang mempunyai nilai tuntas ada $51 \%$, pada sklus pertana meningkat menjadi $67 \%$ dan pada siklus kedua menjadi $78 \%$. Pembelajaran Berbasis Proyek dapat membuktikan dapat meningkatkan prestasi belajar siswa. Selain itu membelajaran dengan menggunakan PjBL juga dapat meningkatkan motivasi belajar peserta didik untuk belajar, mendorong kemampuan mereka untuk melakukan pekerjaan penting, dan mereka perlu untuk dihargai, meningkatkan kemampuan pemecahan masalah, membuat peserta didik menjadi lebih aktif dan berhasil memecahkan problem-problem yang kompleks. 


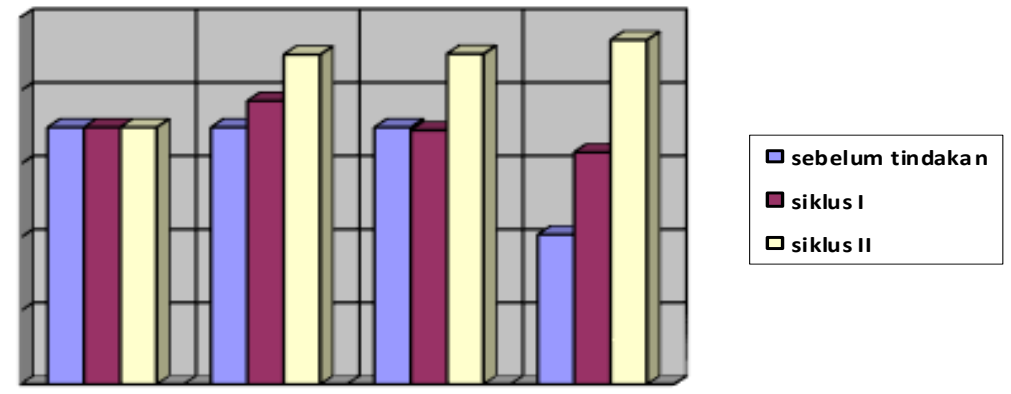

Gambar 2. Perbandingan prestasi belajar siswa sebelum dan sesudah tindakan

Strategi PjBL juga dapat mendorong peserta didik untuk mengembangkan dan mempraktikkan keterampilan komunikasi, meningkatkan keterampilan peserta didik dalam mengelola sumbern memberikan pengalaman kepada peserta didik pembelajaran dan praktik dalam mengorganisasi proyek, dan membuat alokasi waktu dan sumber-sumber lain seperti perlengkapan untuk menyelesaikan tugas, dapat menambah pengalaman belajar yang melibatkan peserta didik secara kompleks dan dirancang untuk berkembang sesuai dunia nyata serta membuat suasana belajar menjadi menyenangkan, sehingga peserta didik maupun pendidik menikmati proses pembelajaran.

\section{SIMPULAN}

Berdasarkan hasil penelitian tentang penerapan strategi pembelajaran project-based learning sebagai upaya meningkatkan prestasi belajar siswa kelas XI IIS-3 di SMA Muhammadiyah 2 Yogyakarta tahun ajaran 2016/2017, peneliti dapat menarik kesimpulan sebagai berikut: (1) Penerapan strategi pembelajaran $\mathrm{PjBL}$ yang dapat meningkatkan prestasi belajar siswa telah diterapkan pada kelas XI IIS 3 di SMA Muhammadiyah 2 Yogyakarta. Proses pembelajaran dilaksanakan dalam dua siklus yaitu siklus I terdiri dari dua pertemuan dan siklus II juga terdiri dari dua pertemuan. Setiap siklus berfungsi untuk mencapai tujuan peneliti yaitu untuk meningkatkan prestasi belajar siswa yang ditunjukkan dengan adanya peningkatan prestasi belajar siswa. Desain penelitian di Siklus I dan siklus II meliputi perencanaan, tindakan, observasi dan refleksi. Pada setiap pertemuan guru menjelaskan materi dan membimbing siswa dalam diskusi pembuatan strategi kebijakan penanganan dampak keanekaragaman masyarakat secara vertikal dan horizontal. Setiap kelompok menyelesaikan proyek untuk di presentasikan di depan dan dikumpulkan kepada guru untuk di publikasikan di web pembelajaran sosiologi sebagai sarana unutk publikasi, (2) Peningkatan prestasi belajar siswa setelah penerapan strategi pembelajaran PjBL. Berdasarkan uraian hasil pelaksanakan penelitian prestasi belajar siswa mengalami penigkatan. Hal itu dapat dilihat dari setiap proses pada siklus I dan siklus II. Kenaikan prestasi belajar didorong oleh aktivitas guru di siklus II meningkat yang diikuti peningkatan aktivitas siswa dalam kerja kelompok pembuatan proyek. Peningkatakan prestasi belajar dapat dilihat dari prosentase hasil evaluasi yang dilaksanakan guru dalam siklus I dan II dengan membandingkan prestasi siswa sebelum pelaksanaan tindak. Sebelum pelaksanaan tindakan prosentase siswa yang tuntas hanya mencapai $51 \%$, setelah di adakan pelaksanaan siklus meningkat $16 \%$. jumlaj siswa yang tuntas di sklus I ada $67 \%$ dan di siklus II prosenrtase kenaikan prestasi siswa meningkat menjadi $78 \%$. Dengan kata lain penerapan strategi PjBL terbukti dapat mendorong peningkatan prestasi belajar siswa.

\section{REFERENSI}

Daryato, H. M. (2011). Penelitian tindakan kelas dan penelitian tindakan sekolah beserta contohcontohnya. Gaya Media.

Qonitah, Q., \& Satyabakti, P. (2014). The effect of participation in "Paguyuban Sehat Kencing Manis" for type 2 diabetics. Jurnal Berkala Epidemiologi, 1(2). 
Rumini, S. (1993). Psikologi pendidikan. Yogyakarta: UPP IKIP Yogyakarta

Sani, R. A. (2014). Pembelajaran saintifik untuk implementasi Kurikulum 2013. Bumi Aksara.

Winkel, W. S. (1983). Psikologi pendidikan dan evaluasi belajar. Gramedia. 